\title{
FAKTOR-FAKTOR YANG BERHUBUNGAN DENGAN WAITING TIME PADA PASIEN TRIAGE KUNING
}

\author{
Milda Aprilian Sari ${ }^{1}$, Susi Erianti ${ }^{2}$, Erna Marni ${ }^{3}$ \\ 1,2,3 Program Studi Keperawatan STIKes Hang Tuah Pekanbaru \\ Email: mildaapriliansari1004@gmail.com
}

\begin{abstract}
ABSTRAK
Waiting time diartikan rentang waktu kedatangan pasien emergency yang diukur mulai dari pasien datang sampai ditransfer keruangan lain. Penumpukan pasien (overcrowded) merupakan masalah yang sering terjadi di Instalasi Gawat Darurat yang dapat menyebabkan waktu tunggu yang lama. Waktu tunggu yang baik dapat meningkatkan mutu pelayanan dan kepuasan yang lebih kepada pasien. Tujuan penelitian ini untuk mengetahui faktor-faktor yang berhubungan dengan waiting time pada pasien triage kuning di IGD RSUD Arifin Achmad Provinsi Riau. Desain yang digunakan dalam penelitian ini adalah observasional analitik dengan pendekatan cross sectional. Sampel dalam penelitian ini adalah pasien yang masuk IGD pada triage kuning dengan teknik pengambilan sampel menggunakan concecutive sampling sebanyak 85 responden. Instrumen penelitian menggunakan lembar observasi dan metode Check List. Hasil bivariat dengan uji chi-square didapatkan bahwa dari empat faktor yang dianalisa terdapat faktor yang berhubungan dengan waiting time adalah waktu kembalinya hasil pemeriksaan laboratorium. Sedangkan faktor-faktor yang tidak berhubungan dengan waiting time pada pasien triage kuning yaitu rasio perbandingan perawat dengan pasien pershift, sarana prasarana, dan adminstrasi. Diharapkan kepada pihak manajemen RSUD Arifin Achmad Provinsi Riau untuk terus mengontrol performa pelayanan pada pemeriksaan penunjang yaitu waktu tunggu kembalinya hasil pemeriksaan laboratorium agar tidak melebihi standar yang telah ditetapkan oleh rumah sakit sehingga dapat mengurangi waktu boarding pasien yang memanjang.
\end{abstract}

Kata kunci: Pasien triage kuning, Waiting Time

\begin{abstract}
Waiting time refers to time span of emergency patients has to spend, starting from patient's arrival to patient being transferred to another room. Overcrowding is a common problem faced at emergency department causing longer waiting time for patients. Shorter waiting time can improve quality of service and patients' level of satisfaction. This study was aimed to determine factors associated with yellow triage patients' waiting time at emergency department of Arifin Achmad General Hospital of Riau Province. This observational-analytic study was carried out using cross sectional approach. Samples of this study were patients entering Emergency Department with yellow triage category, with 85 respondents who were recruited using consecutive sampling technique. Observation sheet and check list method were used as the study instruments. The result of univariate and bivariate analyses using Chisquare test showed that of all four analyzed factors associated with patient waiting time, the most significantly related one was waiting time for laboratory test results. In contrast, the least related factors were nurse-patient ratio per shift, facilities and infrastructures, and administration procedure. It is expected that the management of Arifin Achmad General Hospital of Riau Province to maintain control of the service performance on supporting examination, especially waiting time for the laboratory test result, which will reduce the amount of patient boarding time which keeps extending.
\end{abstract}

Keywords: Yellow triage patient, Waiting Time 


\section{PENDAHULUAN}

Dalam memberikan pelayanan kesehatan, rumah sakit memiliki Standar Operasional Prosedur (SOP) yang bertujuan menjamin kualitas pelayanan maksimal sehingga diharapkan dengan baiknya kualitas pelayanan secara langsung menurunkan angka kesakitan dan resiko kematian serta meningkatkan derajat kesehatan. Rumah sakit memiliki beberapa unit pelayanan diantaranya pelayanan klinik rawat jalan dan rawat inap. Salah satu unit utama yang merupakan unit terdepan pada sebuah rumah sakit serta memegang peranan penting dalam penyelamatan hidup pasien dan merupakan gerbang utama penanganan kasus gawat darurat di rumah sakit adalah Instalasi Gawat Darurat (IGD). Sehingga pelayanan kesehatan di Ruang IGD merupakan tolak ukur utama dari suatu pelayanan rumah sakit atau cerminan dari pelayanan suatu rumah sakit tersebut.

IGD memiliki angka kunjungan paling tinggi disetiap rumah sakit. Kunjungan pasien di Instalasi Gawat Darurat (IGD) tiap tahunnya akan terus bertambah. Peningkatan terjadi sekitar $30 \%$ diseluruh IGD rumah sakit dunia (Bashkin et al, 2015). Data kunjungan pasien masuk ke IGD di Indonesia adalah 4.402.205 pasien $(13,3 \%)$ dari total seluruh kunjungan dirumah sakit umum, jumlah yang sangat signifikan yang berimbas pada mutu pelayanan jika tidak dilayani sesuai dengan standar dan diperlukan juga perhatian yang cukup besar khususnya pada pasien dengan gawat darurat (Menteri Kesehatan RI, 2014).

Salah satu bentuk mutu pelayanan yang sering dikeluhkan oleh pasien adalah lamanya waktu tunggu. Render, dkk (2009) mengatakan waiting time diartikan sebagai orang-orang atau barang dalam barisan yang sedang menunggu untuk dilayani, dalam konteks ini lebih kepada Lenght of Stay (LoS). Waktu tunggu merupakan hal yang sangat penting karena jika waktu tunggu memanjang secara langsung akan mencerminkan kualitas pelayanan kesehatan di ruangan tersebut, hal ini juga dapat memicu ketidakpuasan pasien akan sebuah pelayanan kesehatan. Pasien akan menganggap pelayanan kesehatan jelek apabila sakitnya tidak cepat sembuh, waktu tunggu yang lama, dan petugas kesehatan yang tidak ramah meskipun profesional.

Pasien dengan kategori triage kuning yang menjadi fokus penelitian diambil karena jika tidak diatasi dengan rentang waktu standar akan berpotensi untuk menjadi ke triage merah. Hal ini sesuai dengan penelitian yang dilakukan oleh Fitrio Deviantony (2017) tentang analisis waktu tunggu pasien triage kuning dengan boarding time bahwa ketepatan pelayanan pasien triage kuning dapat menentukan prognosis pasien selanjutnya, yang artinya pasien tidak ada ancaman kematian tapi dapat terjadi kecacatan karena gangguan kesadaran, metabolisme, neurologis dan harus ditangani dalam waktu 15-30 menit. Dengan demikian, banyak akibat yang ditimbulkan dari lamanya waktu tunggu pasien di IGD.

Berbagai faktor berkontribusi terhadap terjadinya permasalahan lamanya waktu yang dialami oleh pasien, seperti perbandingan perawat dan pasien pershif, sarana prasarana, waktu kembalinya hasil pemeriksaan laboratorium, dan administrasi. Selain itu, ada juga faktor karena kurangnya ketersediaan ruangan yang dituju sehingga pasien harus dititipkan keruangan lain dengan ketersediaan alat 
yang ada, keluarga pasien juga harus menunggu keputusan dari pihak keluarga untuk menentukan siapa yang menjadi penanggung jawab keputusan dimana di Indonesia selalu ditentukan oleh anak tertua atau pihak keluarga yang terdekat. Lamanya menunggu hasil pemeriksaan penunjang juga berperan dalam waktu tunggu yang memanjang sehingga juga dapat mempengaruhi waktu penegakan diagnosis.

American Pharmacists Association (2008), menyatakan selain faktor sumber daya manusia, penilaian klinik pasien seperti pemeriksaan fisik dan lamanya hasil pemeriksaan penunjang juga dapat mempengaruhi waktu tunggu yang memanjang. Pemeriksaan penunjang seperti pemeriksaan laboratorium dan pemeriksaan radiologi merupakan informasi yang berharga untuk memonitoring tujuan terapeutik. Selain itu ada juga faktor lamanya penyelesaian kelengkapan administrasi juga berpengaruh, dimana pasien tidak dapat dipulangkan atau dipindahkan keruang perawatan jika administrasi pasien belum lengkap. Romiko (2018) dalam penelitiannya tentang faktorfaktor yang berhubungan dengan lamanya waktu tunggu pasien, mengatakan : didapatkan standar rasio perbandingan perawat dan pasien adalah 1 perawat berbanding 2 pasien, lama waktu kembalinya hasil pemerksaan laboratorium 60 menit, dan proses administrasi didapatkan hasil rata-rata adalah 36,26 menit.

Dari hasil uraian masalah diatas, peneliti tertarik untuk meneliti faktorfaktor yang berhubungan dengan waiting time pada pasien khususnya triage kuning di Instalasi Gawat Darurat RSUD Arifin Achmad Provinsi Riau, karena diharapkan dengan tidak adanya waktu tunggu yang memanjang dapat mengurangi resiko keparahan terhadap pasien dan tentunya berimbas terhadap peningkatan mutu pelayanan dirumah sakit kedepannya.

\section{METODELOGI PENELITIAN}

Jenis penelitian ini menggunakan rancangan analitik kuantitatif . Populasi dalam penelitian ini adalah pasien triage kuning di Rumah Sakit Arifin Achmad Provinsi Riau dengan jumlah pasien sebanyak 108 orang. Sampel dalam penelitian ini adalah pasien triage kuning yang bersedia menjadi responden dan pasien dengan hemodinamik stabil. Pengambilan sampel pada penelitian ini menggunakan teknik consecutive sampling dengan alat pengumpulan data menggunakan lembar observasi dengan metode check-list.

\section{HASIL PENELITIAN}

Hasil penelitian yang dilakukan dari bulan mei sampai juli 2019 pada 85 responden pasien triage kuning di RSUD Arifin Achmad dengan data yang diperoleh sebagai berikut.

\section{A. Karakteristik Responden}

Tabel 1. Distribusi frekuensi usia pasien pada triage kuning di IGD RSUD Arifin Achmad Provinsi Riau

\begin{tabular}{ccccccc}
\hline Usia & $\mathrm{N}$ & Mean & Median & SD & Min & Maks \\
\hline Usia & 85 & 44,14 & 46,00 & 22,167 & 1 & 79 \\
\hline
\end{tabular}

Berdasarkan hasil analisis pada tabel 1 dapat disimpulkan bahwa dari 85 responden, usia minimum responden adalah 1 tahun dan usia maksimal responden adalah 79 tahun, dengan masing-masing nilai mean $=44,14$, median $=46,00$ dan standar deviasi $=$ 22,167 . 
Tabel 2 Distribusi frekuensi karakteristik responden berdasarkan jenis kelamin dan jaminan pasien pada triage kuning IGD RSUD Arifin Achmad Provinsi Riau

\begin{tabular}{clcc}
\hline $\begin{array}{c}\text { Karakteristik } \\
\text { responden }\end{array}$ & & $\mathrm{f}$ & $\%$ \\
\hline Jenis kelamin & Laki-laki & 46 & 54,1 \\
& $\begin{array}{l}\text { Perempua } \\
\mathrm{n}\end{array}$ & 39 & 45,9 \\
& & 85 & 100 \\
\hline Total & Umum & 22 & 25,9 \\
\hline Jenis jaminan & Asuransi & 63 & 74,1 \\
\hline Total & & 85 & 100 \\
\hline
\end{tabular}

Berdasarkan hasil analisis pada tabel 2 dapat disimpulkan bahwa dari 85 responden dengan kategori umur mayoritas dewasa (41-50) sebanyak 18 orang $(21,2 \%)$. Responden yang lebih banyak masuk ke triage kuning mayoritas berjenis kelamin laki-laki sebanyak 46 orang $(54,1 \%)$. Dilihat dari jenis jaminan responden yang masuk yaitu jenis jaminan asuransi atau BPJS sebanyak 63 orang $(74,1 \%)$.

\section{B. Faktor yang berhubungan dengan} waiting time pada pasien triage kuning

Tabel 3 Hubungan perbandingan perawat dan pasien dengan waiting time pada pasien triage kuning di IGD RSUD Arifin Achmad Provinsi Riau

\begin{tabular}{ccccccc}
$\begin{array}{c}\text { sesuai } \\
\text { rasio }\end{array}$ & & 0 & 1 & $\begin{array}{c}2, \\
0\end{array}$ & 0 & 0 \\
\hline Total & 1 & 18, & 6 & 8 & 8 & 10 \\
& 6 & 8 & 9 & 1, & 5 & 0 \\
& & & & 2 & & \\
\hline
\end{tabular}

Berdasarkan hasil analisis tabel 3 dapat diketahui bahwa dari 85 responden yang diteliti, didapatkan pasien yang ditangani oleh perawat yang sesuai rasio hanya 7 orang $(20,0 \%)$ yang sesuai standar, 28 orang $(80 \%)$ tidak sesuai standar waiting time. Sedangkan dari perbandingan perawat dengan pasien yang tidak sesuai rasio ada 9 orang $(18,0 \%)$ yang sesuai standar, dan 41 orang $(82,0 \%)$ tidak sesuai standar waiting time. Hasil uji statistik chisquare diperoleh nilai $\mathrm{p}=0,816$ ( $\mathrm{p}$ value $>\alpha$ ) sehingga tidak terdapat hubungan bermakna antara perbandingan perawat dengan pasien terhadap waiting time pada triage kuning di IGD RSUD Arifin Achmad Provinsi Riau.

Tabel 4 Hubungan sarana prasarana dengan waiting time pada pasien triage kuning di IGD RSUD Arifin Achmad Provinsi Riau

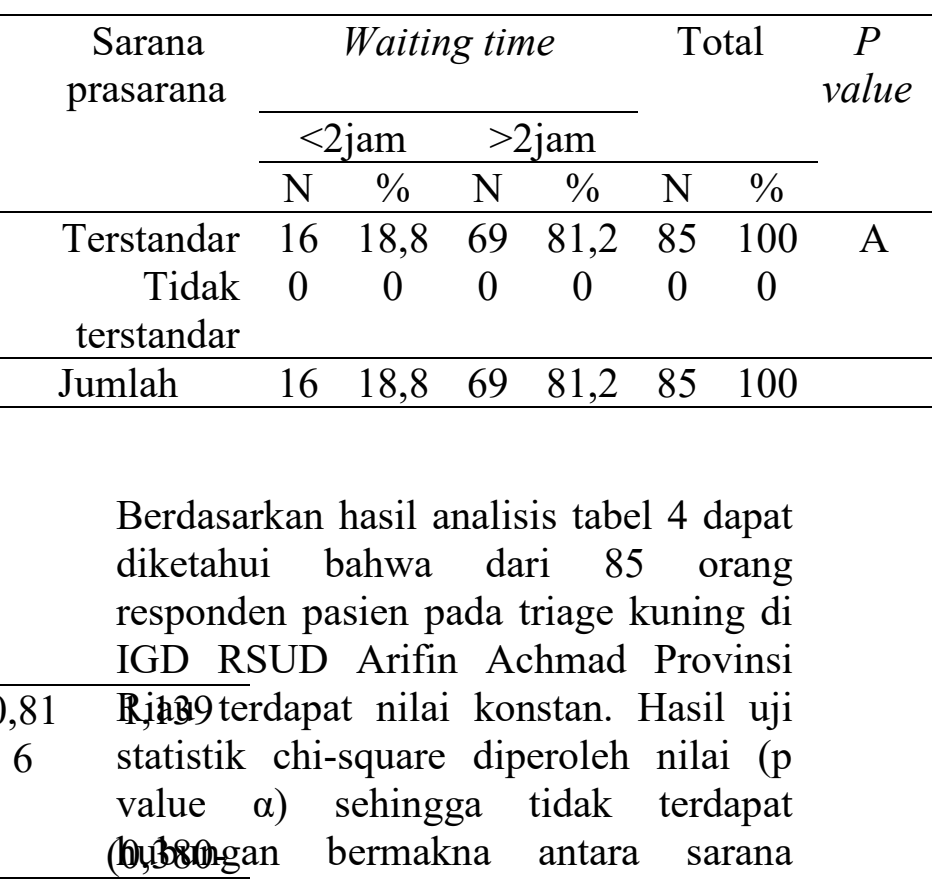


prasarana dengan waiting time pada triage kuning di IGD RSUD Arifin Achmad Provinsi Riau.

Tabel 5 Hubungan waktu kembalinya pemeriksaan laboratorium dengan waiting time pada pasien triage kuning di IGD RSUD Arifin Achmad Provinsi Riau

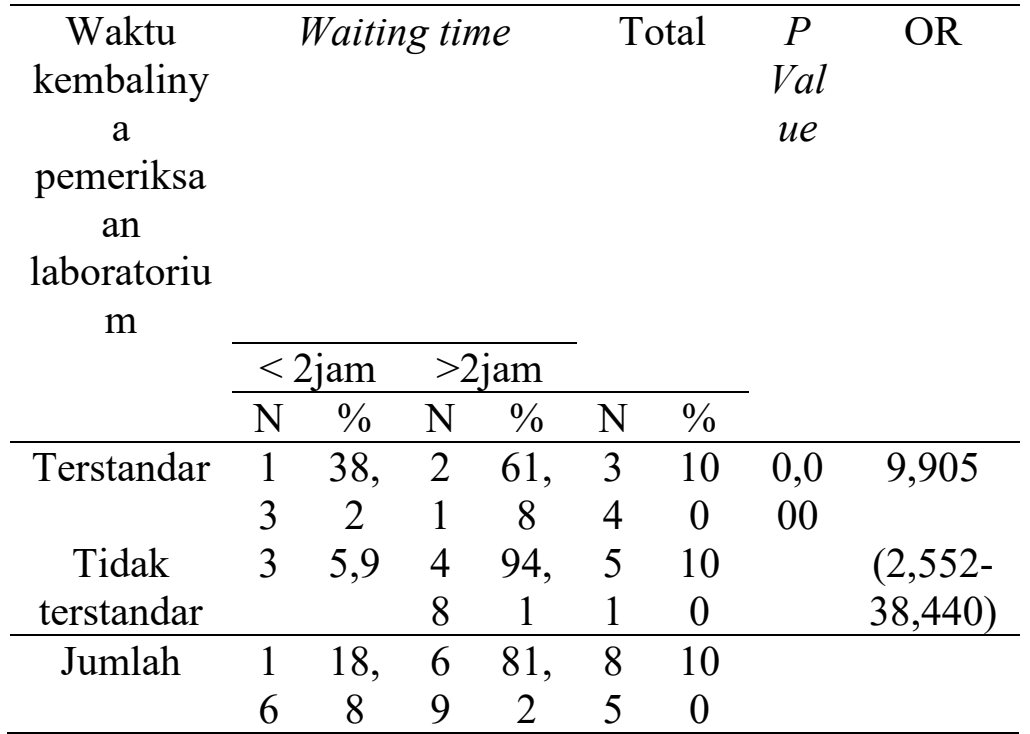

Berdasarkan hasil analisis tabel 5 dapat diketahui bahwa dari 85 responden pasien pada triage kuning di IGD RSUD Arifin Achmad Provinsi Riau yang sesuai standar waktu kembalinya pemeriksaan laboratorium hanya 13 orang $(38,2 \%)$ yang sesuai standar, dan

Berdasarkan hasil analisis tabel 6 dapat diketahui bahwa dari 85 responden pasien pada triage kuning di IGD RSUD Arifin Achmad Provinsi Riau yang sesuai standar administrasi hanya 16 orang $(20,5 \%)$ dan 62 orang $(79,5 \%)$ yang tidak sesuai standar waiting time. Sedangkan yang tidak sesuai standar administrasi hanya 7 orang $(100,0 \%)$ yang tidak sesuai standar waiting time. Hasil uji statistik chi-square diperoleh nilai $p=0,184$ ( $p$ value $>\alpha$ ) sehingga tidak terdapat korelasi yang bermakna
21 orang $(61,8 \%)$ yang tidak sesuai standar waiting time. Sedangkan yang tidak sesuai dengan standar waktu kembalinya hasil pemerksaan laboratorium hanya 3 orang $(5,9 \%)$ yang sesuai standar dan 48 orang $(94,1 \%)$ yang tidak sesuai standar waiting time. Hasil uji statistik chisquare diperoleh nilai $\mathrm{p}=0,000$ ( $\mathrm{p}$ value $<\alpha$ ) sehingga terdapat hubungan bermakna antara waktu kembalinya hasil pemeriksaan laboratorium terhadap waiting time pada triage kuning di IGD RSUD Arifin Achmad Provinsi Riau.

Tabel 6 Hubungan lamanya administrasi dengan waiting time pada pasien triage kuning di IGD RSUD Arifin Achmad

Provinsi Riau

\begin{tabular}{|c|c|c|c|c|c|c|c|}
\hline \multirow{3}{*}{$\begin{array}{l}\text { Administr } \\
\text { asi }\end{array}$} & \multicolumn{4}{|c|}{ Waiting time } & \multicolumn{2}{|c|}{ Total } & \multirow{3}{*}{$\begin{array}{c}P \\
\text { Valu } \\
e\end{array}$} \\
\hline & \multicolumn{2}{|c|}{$<2$ jam } & \multicolumn{2}{|c|}{$>2 \mathrm{jam}$} & & & \\
\hline & $\mathrm{N}$ & $\%$ & $\mathrm{~N}$ & $\%$ & $\mathrm{~N}$ & $\%$ & \\
\hline \multirow[t]{2}{*}{ Terstandar } & 1 & 20 & 62 & 79 , & 78 & 10 & \multirow{4}{*}{$\begin{array}{c}0,18 \\
4\end{array}$} \\
\hline & 6 & 5 & & 5 & & 0 & \\
\hline \multirow{2}{*}{$\begin{array}{c}\text { Tidak } \\
\text { terstandar }\end{array}$} & 0 & 0,0 & 7 & 10 & 7 & 10 & \\
\hline & & & & 0 & & 0 & \\
\hline \multirow[t]{2}{*}{ Jumlah } & 1 & 18 , & 69 & 81 , & 85 & 10 & \\
\hline & 6 & 8 & & 2 & & 0 & \\
\hline
\end{tabular}

antara waktu administrasi terhadap waiting time pada pasien triage kuning di IGD RSUD Arifin Achmad Provinsi Riau.

\section{PEMBAHASAN}

A. Karakteristik responden

1. Karakteristik responden (usia, jenis kelamin, jenis jaminan)

Analisis univariat ini digunakan untuk memperoleh data distribusi frekuensi dan persentase yang dilakukan pada setiap variabel. Berdasarkan hasil 
penelitian yang dilakukan ditemukan bahwa jumlah rata-rata usia responden yang memiliki waktu tunggu lebih dari 2 jam adalah 41-50 tahun (44,14\%). Menurut teori dijelaskan kelompok umur tersebut termasuk golongan usia produktif yang lebih berpotensi mendapatkan resiko penyakit karena masalah penyakit penyerta dan komplikasi penyakit lainnya. Karakteristik responden dengan jenis kelamin terbanyak adalah laki-laki sebanyak 46 responden (54,1\%). Berdasarkan profil kesehatan RSUD Arifin Achmad Provinsi Riau 2018, jumlah kunjungan pasien ke rumah sakit terbanyak yaitu dengan jenis kelamin laki-laki, hal ini juga berkaitan dengan teori yang menyatakan bahwa laki-laki cenderung mudah terkena penyakit yang disebabkan karena beban psikologis, emosional, dan tanggung jawab sebagai kepala keluarga sehingga lebih rentan terhadap penyakit dan lebih cepat menginginkan untuk mendapatkan bantuan kesehatan jika mengalami masalah kesehatan jika dibandingkan dengan perempuan.

Jenis jaminan terbanyak yang digunakan responden sebagian besar adalah jenis jaminan asuransi atau BPJS sebanyak 63 orang $(74,1 \%)$. Profil kesehatan RSUD Arifin Achmad Provinsi Riau menyatakan upaya pelayanan kesehatan pada era BPJS menjadikan rumah sakit sebagai ujung tombak yang sangat penting dalam memberikan pelayanan dari program BPJS kesehatan. Tujuan utama BPJS adalah menjamin agar peserta memperoleh manfaat pemeliharaan kesehatan dan perlindungan dalam memenuhi kebutuhan dasar kesehatan perorangan, mencakup pelayanan promotof, preventif, kuratif dan rehabilitatif. Selain itu, ada juga responden dengan kategori umum dalam hal pembayaran jasa kesehatan di rumah sakit. Hal ini menunjukkan bahwa dengan adanya BPJS berpengaruh terhadap peningkatan jumlah pasien yang berobat ke rumah sakit. Berdasarkan hasil penelitian yang dilakukan, peneliti berasumsi waiting time yang memanjang dengan adanya proses BPJS yang memakan waktu yang cukup lama dan proses yang panjang meskipun sudah dilakukan dengan sistem komputerisasi.

\section{Waiting time}

Berdasarkan hasil penelitian yang dilakukan bahwa responden yang melebihi waktu standar waiting time dua jam sebanyak 69 orang dari 85 responden. Dari hasil penelitian ini dapat digunakan dalam menentukan waktu tunggu pasien yang dimulai dari kedatangan pasien ke IGD sampai pasien keluar dari IGD baik pasien dirawat maupun pasien pulang. Hasil penelitian juga menyatakan bahwa ada faktor lain yang juga turut menyumbang untuk waiting time menjadi memanjang, seperti ketersediaan ruangan rawat inap, pendiagnosaan dokter dan waktu tunggu setelah rawat inap diputuskan. Hal ini sesuai dengan penelitian yang dilakukan oleh Mulyono (2003) yang menyatakan bahwa proses pengambilan keputusan terkait keputusan medis di Indonesia ditentukan oleh budaya dimana pengambilan keputusan terkait tindakan medis baik dalam hal rawat inap adalah anggota keluarga tertua.

\section{B. Faktor-faktor yang berhubungan dengan waiting time pada pasien triage kuning.}

1. Hubungan perbandingan perawat dengan pasien dengan waiting time

Berdasarkan hasil penelitian yang dilakukan terhadap 85 responden menunjukkan bahwa hubungan rasio perbandingan perawat dengan pasien per shift (1:2 atau 1:3) dengan waiting time pada pasien triage kuning di IGD 
RSUD Arifin Achmad Provinsi Riau diketahui tidak terdapat korelasi yang bermakna antara rasio perawat dengan pasien dengan waiting time dengan $\mathrm{p}$ value $0,816>0,05$. OR 1,139 yang artinya status perawat tidak sesuai rasio berisiko 1,139 kali memiliki waiting time $>2$ jam jika dibandingkan dengan status perawat sesuai rasio, dimana rasio standar nya $1: 2$. Penelitian ini menggambarkan bahwa setiap pasien yang masuk IGD pada triage kuning masih dapat ditangani oleh jumlah perawat yang ada dengan metode tim. Metode tim ini adalah bagian dari metode pemberian asuhan keperawatan profesional kepada pasien yang disesuaikan dengan ketenagakerjaan, sarana prasarana, dan kebijakan rumah sakit.

Metode keperawatan tim adalah metode pemberian asuhan keperawatan dimana seorang perawat profesional memimpin sekelompok tenaga keperawatan dengan berdasarkan konsep kooperatif dan kolaboratif (Douglas, 1994). Keuntungan dari metode tim ini mekanisme kerjanya sangat terkoordinasi sehingga masalah keperawatan diruangan dapat diatasi. Dan ketika peneliti melakukan wawancara kepada perawat IGD menyebutkan bahwa, perawat masih mampu menangani jumlah pasien yang datang pada triage kuning. Kecuali, jika ada wabah atau kejadian luar biasa yang masuk ke IGD secara serentak maka akan berdampak pada peningkatan beban kerja yang menyebabkan waiting time memanjang. Namun, faktanya jika pasien masih berada di ruangan IGD sehingga menyebabkan LoS memanjang karena disebabkan oleh faktor lainnya.

Penelitian ini sejalan dengan Peraturan Menteri Kesehatan Republik Indonesia Nomor. 262/MENKES/Per/VII/1979 yang menyatakan bahwa perkiraan jumlah pekerja yang perlu dipertimbangkan dalam mengkaji beban kerja tenaga perawat yaitu rasio pasien dan perawat, rasio tempat tidur, serta perlunya hubungan kerja non keperawatan yang dilakukan oleh perawat seperti transportasi pasien. Jumlah perawat dan jumlah pasien yang tidak berimbang menyebabkan peningkatan beban kerja perawat. Rasio tempat tidur dan perawat untuk rumah sakit tipe A dan B adalah 1:2 pasien.

Hasil penelitian ini tidak sejalan dengan penelitian yang dilakukan oleh Deviantony, Ahsan, \& Setyoadi (2017) menyebutkan bahwa adanya hubungan antara perbandingan perawat dengan pasien per jaga dengan waktu tunggu pasien setelah keputusan rawat inap diputuskan dengan arah hubungan negatif. Hal ini memiliki arti bahwa ketika rasio perawat dengan pasien per shift semakin besar maka nilai waktu tunggu pasien setelah keputusan rawat inap diputuskan akan semakin kecil, begitu pula sebaliknya apabila nilai rasio perawat dengan pasien per shift semakin kecil maka nilai waktu tunggu pasien setelah keputusan rawat inap diputuskan akan semakin besar atau memanjang.

Namun, hasil penelitian ini sejalan dengan penelitian yang dilakukan oleh Nurmansyah, susilaningsih \& Setaiawan (2014) mengatakan bahwa jika observasi dilakukan pada pasien dengan tingkat ketergantungan total atau triage merah IGD RSUD Arifin Achmad Provinsi Riau rasio perbandingan perawat dan pasien harus 1:1. Maka, dengan keadaan ketersediaan jumlah perawat yang ada sehingga dapat menjadi faktor yang sangat berhubungan waiting time pada rasio perbandingan perawat dan pasien pershift 
Dari hasil penelitian yang dilakukan bahwa, tidak terdapat hubungan rasio perawat dengan pasien dengan waiting time pada triage kuning di IGD RSUD Arifin Achmad Provinsi Riau, namun jika terdapat waiting time memanjang hal ini disebabkan oleh faktor lain yaitu ketersediaan ruangan, transfer pasien, dan waktu tunggu hasil laboratorium.

\section{Hubungan sarana prasarana dengan waiting time}

Berdasarkan hasil penelitian yang dilakukan terhadap 85 responden menunjukkan bahwa sarana dan prasarana pada pasien triage kuning dengan waiting time pasien triage kuning di IGD RSUD Arifin Achmad Provinsi Riau diketahui tidak terdapat korelasi yang bermakna dengan $p$ value konstan, dimana itu artinya semuanya sudah sesuai standar. Meskipun sarana prasarana yang digunakan portabel tetapi masih mencukupi untuk menangani setiap pasien yang datang ke IGD sesuai dengan standar operasional prosedur dan kriteria penyakit khususnya pada pasien triage kuning di IGD RSUD Arifin Achmad Provinsi Riau. Hasil wawancara dengan kepala ruangan yang dilakukan dikemukakan bahwa semua perawat ruangan tersebut sudah megikuti pelatihan, sehingga semua perawat sudah sangat menguasai dan profesional dalam melakukan tindakan keperawatan terhadap pasien.

Penelitian ini sejalan dengan standar pelayanan di IGD yang dijelaskan dalam Keputusan Menteri Kesehatan Republik Indonesia (2009) berdasarkan Standar Pelayanan Minimal (SPM) Rumah Sakit (2008), harus menetapkan standar ketersediaan sarana dan prasarana pelayanan yang memadai sehingga pasien merasakan kepuasan dalam mendapatkan pelayanan yang diberikan. Permasalahan yang sering timbul dan sangat serius karena kurangnya sarana dan prasarana yang ada untuk mendukung pelayanan kesehatan, sehingga hal tersebut sangat mempengaruhi pelayanan kesehatan kepada masyarakat dan menyangkut pelayanan bagi orang banyak. Sarana dan prasarana yang harus tersedia selain yang ditentukan oleh standar level di IGD rumah sakit tergantung juga dari kasus yang ditangani, antara lain ruang triage yang memenuhi standar dengan adanya ketersediaan kit pemeriksaan sederhana, brankard penerimaan pasien, label pasien. Imobilization set seperti oksigen, ventilator transport, ECG, Vital sign monitor, vena section, termometer, stetoskop, nebulizer, infusion pump, syringe pump, urine bag. Obat-obatan habis pakai seperti cairan infus, adrenalin, sulfat atropin, kortikosteroid, lidocain, aminophilin, manitol, furosemide, trombolitik, ATS, TT, APD.

Penelitian ini tidak sejalan dengan yang dikemukakan oleh Nurmansyah, Susilaningsih \& Setiawan (2014), dalam jurnalnya tentang tingkat ketergantungan dan lama perawatan pasien rawat observasi, bahwa tertahannya pasien diruang IGD disebabkan oleh bebrapa faktor seperti terbatasnya persediaan tempat tidur, dan kurang tersedianya regulator oksigen. Terbatasnya persediaan peralatan medis dapat menghambat akses pasien yang akan dirawat inap, sehingga ketersediaan sarana termasuk pengadaan alat kesehatan harus berorientasi pada kondisi di pelayanan.

Dari hasil penelitian yang dilakukan bahwa, tidak terdapat hubungan sarana prasarana dengan waiting time khususnya pada pasien triage kuning di IGD RSUD Arifin Achmad Provinsi Riau. Namun, jika ditemukan waiting time pasien memanjang disebabkan oleh beberapa faktor seperti faktor ketersediaan tempat tidur diruangan, 
lama tinggal pasien rawat inap dan kompleksitas kondisi pasien.

\section{Hubungan waktu kembalinya hasil pemeriksaan laboratorium}

Berdasarkan hasil penelitian yang dilakukan terhadap 85 responden menunjukkan bahwa hubungan standar waktu 60 menit untuk waktu kembalinya hasil pemeriksaan laboratorium dengan waiting time pada pasien triage kuning di IGD RSUD Arifin Achmad Provinsi Riau diketahui terdapat korelasi yang bermakna dengan $\mathrm{p}$ value $0,000<0,05$. OR 9,905 yang artinya waktu kembalinya hasil pemeriksaan laboratorium tidak sesuai standar berisiko 9,905 kali memiliki waiting time $>2$ jam jika dibandingkan dengan waktu kembalinya hasil pemeriksaan laboratorium sesuai standar. Penelitian ini menggambarkan bahwa setiap pasien yang masuk IGD pada triage kuning tetap akan menunggu hasil pemeriksaan penunjang seperti pemeriksaan laboratorium untuk dapat diberikan advice selanjutnya oleh dokter dan apa tindakan yang harus dilakukan. Sehingga sangat berdampak pada waiting time pasien yang memanjang di IGD. Waktu kembalinya hasil pemeriksaan laboratorium yang memanjang disebabkan karena ketersediaan sarana dan prasarana sera petugas labor yang terbatas, dan banyaknya permintaan pemeriksaan labor, meskipun alat yang digunakan sudah menggunakan sistem komputerisasi.

Penelitian ini sejalan dengan teori bahwa pemeriksaan penunjang wajib dilakukan untuk menentukan diagnostik pasien, yang meliputi pemeriksaan laboratorium dan pemeriksaan radiologi. Sistem pemeriksaan laboratorium di IGD melalui berbagai proses. Pemeriksaan laboratorium dengan pemanfaatan komputerisasi dalam analisa darah laboratorium dan pencatatannya dapat mengurangi jumlah penumpukan pasien di IGD dan dapat berdampak langsung terhadap kualitas perawatan dan kepuasan pasien. Dapat disimpulkan dengan membaiknya pelayanan laboratorium dapat memberikan dampak positif pada pelayanan dan kepuasan pasien (Hodgins et al, 2011). Hal ini juga sejalan dengan hasil penelitian terdahulu yang dilakukan oleh Steindel \& Howanitz (2001) yang menyatakan bahwa pemeriksaan laboratorium dilakukan pada pasien yang berkunjung ke IGD dan dirawat di rumah sakit termasuk yang dipulangkan dengan standar waktu 60 menit yang dimulai dari waktu order dokter sampai hasil tiba di IGD.

Dari hasil penelitian yang dilakukan bahwa, terdapat hubungan waktu kembalinya hasil pemeriksaan laboratorium dengan waiting time pasien pada triage kuning di IGD RSUD Arifin Achmad Provinsi Riau, hal ini disebakan oleh beberapa faktor seperti ketersediaan alat yang belum memadai sehingga harus menunggu selesai hasil pemeriksaan pasien sebelumnya. Selain itu, berdasarkan standar teori posisi laboratorium terpusat dilabor central dan berpusat di IGD sehingga hasil permintaan labor dapat cepat diketahui dengan jarak yang dekat. Hal ini juga yang membuat salah satu faktor waktu kembalinya pemeriksaan laboratorium jadi memanjang.

\section{Hubungan waktu administrasi}

Berdasarkan hasil penelitian yang dilakukan terhadap 85 responden menunjukkan bahwa hubungan standar waktu 10 - 15 menit untuk waktu administrasi dengan waiting time pada pasien triage kuning di IGD RSUD Arifin Achmad Provinsi Riau diketahui tidak terdapat korelasi yang bermakna 
dengan $p$ value $0,184>0,05$. OR 0,795 yang artinya waktu administrasi tidak sesuai standar berisiko 0,184 kali memiliki waiting time $>2$ jam jika dibandingkan dengan waktu sesuai standar. Dari hasil observasi yang dilakukan menunjukkan bahwa petugas administrasi yang merupakan petugas dari rekam medis dimana ruangannya masih berada dekat dengan IGD sehingga memudahkan pasien dalam pengurusan jaminan rawatannya. Untuk pasien yang sudah memiliki asuransi kesehatan atau BPJS tidak perlu lagi lama menunggu karena input data yang mudah diakses. Jika faktanya masih ada waiting time pasien yang memanjang itu disebabkan beberapa faktor seperti kesepakatan antara keluarga, dan menunggu ketersediaan ruangan yang dituju jika pasien harus dirawat, atau ketidaklengkapan dari syarat jaminan pasien tersebut.

Penelitian ini sejalan dengan teori yang dikemukakan dalam Keputusan Menteri Kesehatan Republik Indonesia (2009) berdasarkan Standar Pelayanan Minimal (SPM) Rumah Sakit (2008) pendaftaran pasien Instalasi Gawat Darurat dilakukan diruang pendaftaran pasien yang ada didalam ruangan IGD. Petugas pendaftaran adalah petugas dari Instalasi Rekam Medis yang ditugaskan dalam 24 jam yang dibagi dalam tiga shif, yaitu shif pagi, sore dan malam. Sistem penomoran rekam medis pasien IGD adalah penomoran sentral dari Instalasi Rekam Medis Rumah Sakit. Pasien IGD memakai kartu khusus IGD sesuai dengan data yang diperlukan dalam pencatatan dan pelaporan IGD tersebut. Standar pelayanan administrasi untuk pasien rawat inap di IGD adalah 15 menit, dan untuk pasien rawat jalan 10 menit.

Hasil penelitian yang dilakukan ini juga sejalan dengan penelitian yang dilakukan oleh Deviantony, Ahsan \& Setyoadi (2017) bahwa tidak ada hubungan antara kepemilikan asuransi dengan waktu tunggu pasien setelah keputusan rawat inap diputuskan di zona kuning. Adapun terdapat perbedaan dengan penelitian yang dilakukan oleh Kennedy et al (2004), terjadi delay atau penundaan dalam pelayanan terjadi karena permasalahan biaya pelayanan yang meningkat.

Dari hasil penelitian yang dilakukan bahwa, tidak terdapat hubungan pada lamanya administrasi dengan waiting time pada pasien triage kuning di IGD RSUD Arifin Achmad Provinsi Riau. Namun, meskipun masih ada terdapat waiting time yang memanjang dikarenakan proses tekhnis lainnya seperti keputusan keluarga pasien dalam hal memutuskan untuk dirawat, menunggu persiapan pasien dalam hal pemeriksaan penunjang lainnya.

\section{KESIMPULAN}

Berdasarkan hasil penelitian yang telah dilakukan oleh peneliti mengenai faktor-faktor yang berhubungan dengan Waiting Time pada pasien triage kuning di IGD RSUD Arifin Achmad Provinsi Riau tahun 2019 terhadap 85 responden, dapat disimpulkan bahwa

1. Tidak ada hubungan rasio perbandingan perawat dengan pasien pershift dengan Waiting Time pada pasien triage kuning di IGD RSUD Arifin Achmad Provinsi Riau.

2. Tidak ada hubungan sarana prasarana peralatan medis dengan Waiting Time pada pasien triage kuning di IGD RSUD Arifin Achmad Provinsi Riau.

3. Terdapat hubungan pada pemeriksaan penunjang yaitu waktu kembalinya hasil pemeriksaan laboratorium dengan Waiting Time pada pasien triage kuning di IGD RSUD Arifin Achmad Provinsi Riau. 
4. Tidak ada hubungan waktu administrasi jaminan rawatan dengan Waiting Time pada pasien triage kuning di IGD RSUD Arifin Achmad Provinsi Riau.

\section{SARAN}

1. Bagi pihak rumah sakit ruangan terkait

Diharapkan pada pihak manajemen rumah sakit dan ruangan pada pihak terkait agar lebih memperhatikan ketersediaan sarana prasarana yang menunjang kelancaran operasional untuk pemeriksaan penunjang pasien yaitu pada waktu pemeriksaan labor, dan dapat menerapkan standar waiting time pada pasien triage kuning di IGD RSUD Arifin Achmad Provinsi Riau yang sesuai sehingga tidak terjadi waktu tunggu pasien yang memanjang, sehingga pelayananan terhadap pasien sesuai standar waktu dapat tercapai.

2. Bagi peneliti selanjutnya

Diharapkan bagi peneliti selanjutnya bisa melakukan penelitian yang sama dengan menggunakan metode penelitian yang berbeda sehingga peneliti lebih memahami segala sesuatu yang berkaitan dengan kejadian waiting time pada pasien triage kuning di IGD RSUD Arifin Achmad Provinsi Riau.

\section{DAFTAR PUSTAKA}

American Pharmacist Association. (2008). Medscape Conference Coverage. Sandiego. California.

Bashkin,O., Caspi,S., Haligoa,R., Mizrahi,S., \& Stalnikowicz,R. (2015). Organizational Factor affecting length of stay in the emergency department : Initial observational study Israel Journal of Health Policy Research,4,38. https://doi.org/10.1186/s13548015-0035-6

Deviantony,Fitrio., Ahsan., Setyoadi. (2017). Analisis Faktor Yang Berhubungan dengan Waktu Tunggu Pasien Setelah Keputusan Rawat Inap Diputuskan di Zona Kuning Instalasi Gawat Darurat RSUD dr. Iskak Tulung Agung. NurseLine Journal : Vol.2 No.2 pISSN 2540-7937 e-ISSN 2541464X.

Douglass, Laura Mae \& Em Olivie Bevis. (2004). Nursing Management and Leadership In Action. Missouri : The CV. Mosby Company.

Heizer, Jay dan Barry Render. (2009). Manajemen Operasi Buku I Edisi 9. Jakarta. Salemba 4

Hodgins, MJ., Moore, N., \& Legere,L. (2011). Who is sleeping in Our Beds? Factor predicting the ED Boarding of Admitted Patiens For Nursing, Than 2 Hours. Journal of Emergency Nursing, 37(3), 225-230.

https://doi.org? 10.1016/j.jen.2010 .02 .020 .

Menteri Kesehatan Republik Indonesia. (2009). "Keputusan Menteri Kesehatan Republik Indonesia Nomor 856 / menkes / sk / ix / 2009 tentang Standar Instalasi Gawat Darurat ( IGD ) Rumah Sakit." Keputusan Menteri Kesehatan Republik Indonesia.

Menteri Kesehatan RI. (2014). Peraturan Menteri Kesehatan Republik Indonesia Nomor 28 Tahun 2014 tentang Pedoman Pelaksanaan Program Jaminan Kesehatan Nasional. Kementrian 
Kesehatan

RI,1-

48.https://doi.org/10.1002/cplu.

Nurmansyah, Susilaningsih \& Setiawan. (2014). Tingkat Ketergantungan dan Lama Perawatan Pasien Observasi di IGD. NurseLine Journal :Vol.2 No.3

Romiko. (2018). Faktor-faktor yang berhubungan dengan lama waktu tunggu pasien di IGD RS Muhammadiyah Palembang. Jurnal 'Aisyiyah Medika Volume 2.

Rumah Sakit Umum Daerah Arifin Achmad Provinsi Riau. (2009). Standar Pelayanan Minimal Rumah Sakit Umum Daerah Arifin Achmad. Pekanbaru.

Rumah Sakit Umum Daerah Arifin Achmad Provinsi Riau. (2018). SOP Rumah Sakit. Pekanbaru. RSUD Arifin Achmad Provinsi Riau.

Wiler, JL., Handel, DA., Ginde, AA., Aronsky, D., Genes, NG., Hackman, JL, JL., \& Fu, R. (2012). Predictors of patient length of stay in 9 emergency departments. American Journal of Emergency Medicine, 30(9), 1860-1864. https://doi.org/10.1016/j.ajem.2012.0 3.128 